\title{
ORACLES ON FAULTS: A PROBABLE LOCATION OF A "LOST" ORACLE OF APOLLO NEAR OROVIAI (NORTHERN EUBOEA ISLAND, GREECE) VIEWED IN ITS GEOLOGICAL AND GEOMORPHOLOGICAL CONTEXT
}

\author{
I. Mariolakos ${ }^{1}$, V. Nikolopoulos ${ }^{2}$, I. Bantekas ${ }^{1}$, N. Palyvos ${ }^{3}$ \\ ${ }^{1}$ University of Athens, Faculty of Geology, Dynamic, Tectonic and Applied Geology Department, \\ Panepistimioupolis Zografou, 157 84, Athens, Greece, mariolakos@geol.uoa.gr, \\ pandaemonium12@yahoo.gr \\ ${ }^{2}$ Ministry of Culture, 2nd Ephorate of Prehistoric and Classical Antiquities, L. Syggrou 98-100, \\ 11741 Athens, Greece, vanpep@otenet.gr \\ ${ }^{3}$ Harokopio university, Department of Geography, El. Venizelou 70 (part-time) / Freelance Geologist, \\ Navarinou 21, 15232 Halandri, Athens, Greece,palyvos@gmail.com
}

\begin{abstract}
At a newly discovered archaeological site at Aghios Taxiarches in Northern Euboea, two votive inscribed stelae were found in 2001 together with hellenistic pottery next to ancient wall ruins on a steep and high rocky slope. Based on the inscriptions and the geographical location of the site we propose the hypothesis that this is quite probably the spot where the oracle of "Apollo Selinountios" (mentioned by Strabo) would stand in antiquity. The wall ruins of the site are found on a very steep bedrock escarpment of an active fault zone, next to a hanging valley, a high waterfall and a cave. The geomorphological and geological environment of the site is linked directly to the regional geodynamical context of Central Greece, a region of tectonic turmoil throughout the Pleistocene and Holocene, characterised by distinct landscapes produced by the activity of active fault zones, intense seismicity, and in part, volcanism and hydrothermal activity. The geomorphological and geological similarities of the Ag. Taxiarches site with those of the oracle at Delphi, seem to provide further support to the hypothesis that the former site can well be that of an ancient oracle, given the recently established connections between the geological environment at Delphi and Apollo's oracle there. Definitive verification of our hypothesis can only be obtained by further, detailed archaeological study, whereas geological/geomorphological, geochemical, and geochronological studies would be necessary to clarify the connection that the cave lying next to the wall remains may had with the site's function.
\end{abstract}

Key words: Apollo Selinaios, oracle, geodynamics, geomorphology, Euboea (Evia).

\section{Introduction}

The purpose of this paper is to present a resume of the available archaeological data and the results of a geological and geomorphological reconnaissance of a recently discovered archaeological site near Rovies, North Euboea (or Evia) (Figure 1). We will propose that the available literary, archaeological and geographical data, support the hypothesis that this site could well be the oracle of Apollo Selinountios, mentioned by Strabo $(10,1,3)$ in his description of the northern part of the island. The 


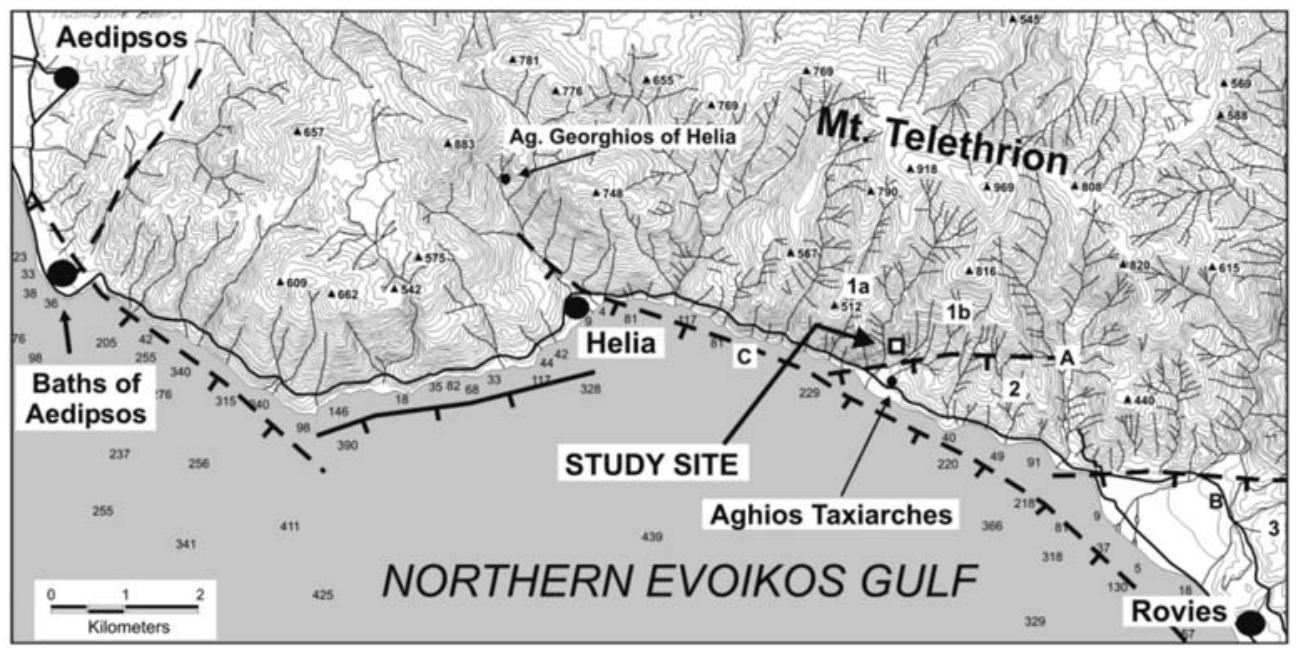

Fig. 1: Topographic map of the broader area of the study site (Telethrion mountain). $20 \mathrm{~m}$ contours from 1:50,000 HAGS topographic maps. On shore faults modified from the IGME geological map (Katsikatsos et al., 1984), and from this study. Major offshore fault traces are based on Van Andel \& Perissoratis (2006), with modifications (see also Sakellariou et al., 2007 for smaller scale map). A great number of thermal springs are found in the Baths of Aedipsos (Loutra Aedipsou) and in Helia, which are accompanied by the emission of gasses. 1a: Triassic metavolcanics and crystalline limestones, 1b: Triassic metaclastics, 2: Permian metaclastics, 3: Neogene fluvio-lacustrine deposits of the Limni-Istiaia basin (Katsikatsos et al., 1984)

geomorphic and geological characteristics of the site will be presented and compared to those of the oracle of Apollo at Delphi, in order to bring forward the similarities existing between the two. Since recent studies have established the strong connection between the geological characteristics and phenomena at the famous oracle of Apollo at Delphi, and the particular use of the site in ancient times (Piccardi, 2000; de Boer and Hale, 2000; de Boer et al, 2001), this comparison provides further, indirect support to the hypothesis that the site discussed herein can well be the site of an oracle.

\section{A cult place dedicated to Apollo Selinaios at Aghios Taxiarches and the oracle of Apollo Selinountios mentioned by Strabo}

In 2001, at the steep western slope of Mt. Telethrion, in the vicinity of the chapel of Aghios Taxiarches, near the western euboean coast and $6.2 \mathrm{~km} \mathrm{NW}$ of the village of Rovies (Figure 1), a votive inscribed stele and a fragment of a second one were discovered by a citizen and handed over to the Greek Archaeological Service where they were given the inventory numbers 216 and 217 of the Aedipsos Archaeological Collection. They were found, in a crack on bedrock and on the ground surface, together with surface pottery, identified as Hellenistic (see Nikolopoulos, 2005), right next to the ruins of a wall made of large, roughly worked blocks (Figure $2 \mathrm{a} / \mathrm{b}$ ). The wall, possibly part of an enclosure or of a retaining wall is preserved for a length of $13 \mathrm{~m}$ and ends abruptly to the North, apparently due to landsliding. The steepness of the terrain at the site, the high rock-fall hazard and potential increased slope instability do not allow a safe archaeological trial excavation at the moment. In any case, the slope and the wall sustains only a limited amount of soil covering the bedrock on which the wall remains rest, i.e., valuable archaeological evidence has been obviously washed away from the site. 
The inscription no 216 (Figure 2c), mentions the dedication of a female slave to Apollo Selinaios so that after a certain time she could obtain her liberty. There are also mentioned the names of the dedicator and the authorities who were present. According to the type of the letters, it is dated in the 1st half of the 1st century BCE. The fragment No 217 (Figure 2d), mentions in its $1^{\text {st }}$ verse the town-

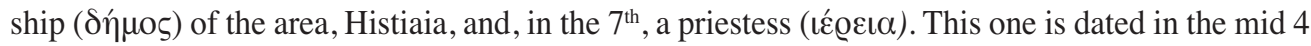
th century BCE (Nikolopoulos, 2005).

Aed. Coll. inv. No 216
[- - - - - - ] $A[\ldots]$

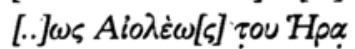

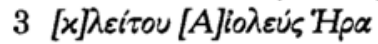

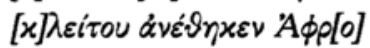

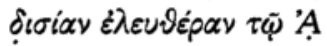

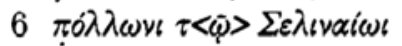

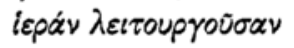
$\tau \tilde{\varphi} \vartheta \varepsilon \tilde{\omega} l \cdot \dot{\rho} \chi \chi o ́ v \tau \omega \nu \pi \alpha$

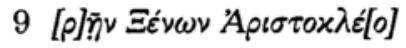

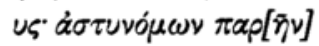

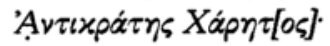

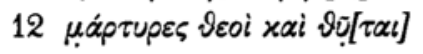
vacat

Aed. Coll. inv. No 217

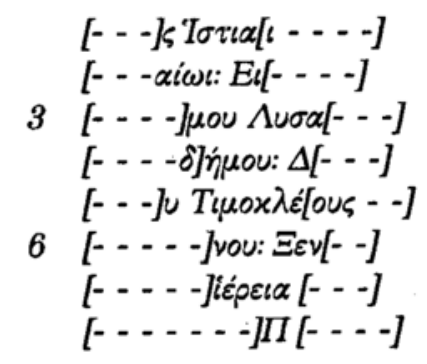

We have seen that, according to the epigraphical material, a citizen of unknown provenance dedicated, at the study site, a slave to a sanctuary of Apollo, bearing an epithet unknown from any literary or epigraphical source. Liberation via dedication to the services of a god was a common practice in hellenistic and roman times, especially in east/central Greece, mainly in Boeotia, Phokis and Lokris, westwards of Northern Euboea. Over two hundred hellenistic and roman inscriptions refer to the dedication of slaves at sanctuaries, mainly of Asklepios, Sarapis, Zeus, Herakles, Artemis Eileitheia and Apollo (Darmezin, 1999), all deities and heroes with healing properties or related with medicine.

In Northern Euboea the cult of Apollo is mentioned only in one ancient source, in a passage of Strabo (10.1.3), where he mentions an oracle of Apollo Selinountios located in the area of Oroviai.

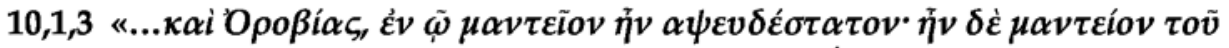

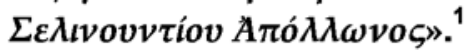

Various authors and scholars dedicated to the topography of ancient Euboea refer to this information, but have failed to spot the location of the oracle. Following a modern legend it was widely accepted - by historians and among monastic circles- that the oracle should not be next to ancient Oroviai (mdn. Rovies - Figure 1) ${ }^{2}$, where Strabo located it, but farther North, under the XVI century monastery of Aghios Georghios of Helia (Figure 1, Bursian, 1872, 411, n. 2; Sackett et al., 1966, 39 n. 25).

\footnotetext{
1 "... and Orovia; in this last place was an oracle most averse to falsehood (it was an oracle of Apollo Selinountios)..." Trans. H. L. Jones, The Geography of Strabo, Vol. V, The Loeb Classical Library, CA Massachusetts, Harvard University Press, London, 1988. (In this edition instead of the right transliteration Oroviai/Oroviae the toponym appears as Orovia).

${ }^{2}$ The ancient Oroviai stood where the modern village of Rovies is, $6.2 \mathrm{~km}$ SE of the chapel of Aghios Taxiarches. Today classical or later ruins and pottery are visible on the sides and on the top of a hill within the limits of the village where, according to Sackett et al. $(1966,47)$, the town must have moved from the nearby coast after the destruction it suffered by the earthquake of 426 BCE mentioned by Thucidides $(3,89)$.
} 

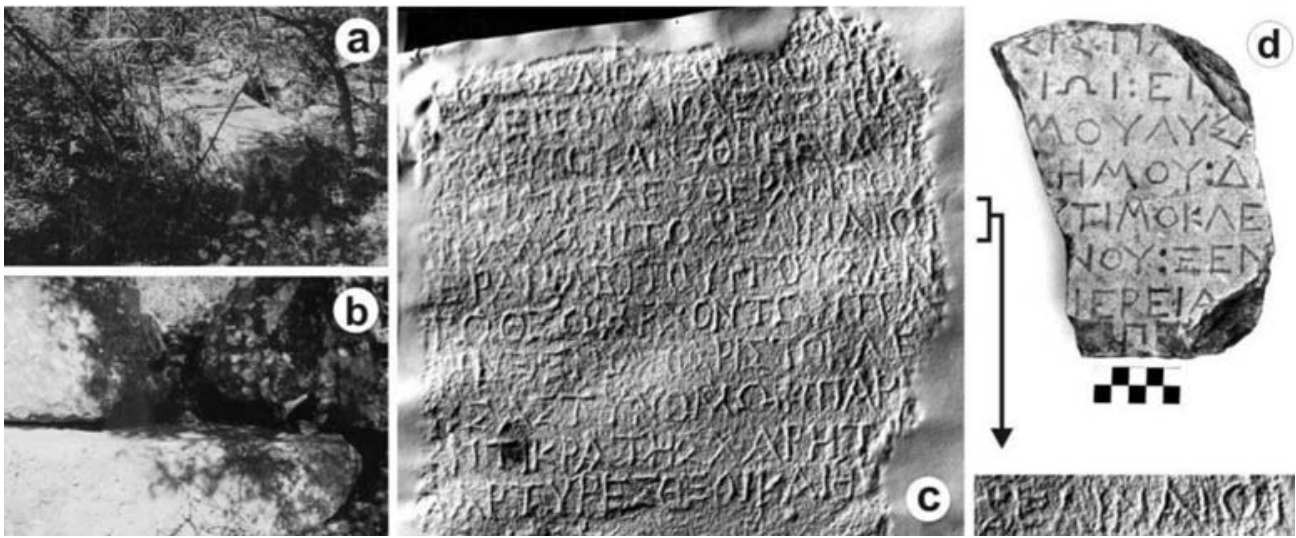

Fig. 2: (a) / (b): Walling remains of the site of Apollo Selinaios. c, d: The inscribed stelae found at the same site (Nikolopoulos, 2005). The stele at (c) is dated at the 1st half of the 1st century BCE and mentions the dedication of a slave to Apollo Selinaios ( $\mathrm{E} \Lambda \mathrm{INAI} \Omega \mathrm{I})$ so that after a certain time she could obtain her liberty. The stele at (d) mentions the major township (demos) of the area, Histiaia, and a priestess (IEPEIA), and is dated at mid 4th century BCE.

A sanctuary of Apollo with oracular function is not unexpected in the area. In the Homeric Hymn to Apollo, a detailed description is given of the route taken by Apollo, in his quest for an appropriate site to found his oracle (Figure 3). Starting from Mt. Olympus, he headed south and, through Iolkos (in Thessaly), he arrived at cape Kenaeon (cape Lichas) of Northern Euboea. From there, following a route along the west coast of the island he reached the Lelantion field and he subsequently wandered westwards towards the area of Boeotia, before ending up in Phokis, where he founded the oracle of Delphi. The hymn describes how local deities were put under Apollo's domination and how at least one sacred place with a spring (Telphoussa, 9 in Figure 3) was destroyed upon resisting the domination of the god. It is remarkable that the site at Aghios Taxiarches, (AS in Figure 3), is located on the mythological route described in the Homeric Hymn. (Figure 3).

Considering the above, the epithet Selinaios used for Apollo in one of the inscriptions at the study site and the site's proximity to ancient Oroviai, the hypothesis that the ruins at the study site can be identified with the oracle of Apollo Selinountios mentioned by Strabo, in our view is a very plausible one. In Strabo's text of course, the epithet used for Apollo is "Selinountios", whereas inscription No 216 is dedicated to Apollo "Selinaios". The two epithets are not interchangeable, raising the question whether the text of Strabo may refer to a different site than one where the inscription referring to Selinaios Apollo was found. The name "Selinountios" could suggest a connection with the towns of Selinous in Sicily or a minor town with the same name on the island of Peparethos, NE of Euboea (today's Skopelos Island - Figure 3). Etymologically, both words (Selinountios and Seli-

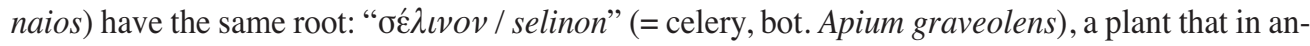
tiquity had given indeed its name to rivers, lakes, towns, local deities or heroes in mainland Greece, the Aegean, Asia Minor and Sicily (RE $\left.{ }^{3}, \Sigma \varepsilon \dot{\lambda} \iota v o \varsigma, \Sigma \varepsilon \lambda \iota v o v ́ \varsigma\right)$. Considering that: (1) Strabo was based often on earlier written sources, (2) a literary text the original of which is not known may have suffered changes through the centuries by successive copiers, (3) the connections implied by the epithet Selinountios cannot be testified by any historical or archaeological source, (4) that the epithet

\footnotetext{
${ }^{3}$ Paulys Real Encyclopädie der Classischen Altertumswissenschaft.
} 
Selinaios is unknown from any literary or epigraphical source and that (4) the hypothesis that next to Oroviai there were two different cult places dedicated to Apollo, bearing as epithets variations of the same root "selinon" is perhaps much weaker than the hypothesis that the epithet mentioned in Strabo is a result of error of transcription, based on the data available at the moment, we tend to favour the latter hypothesis. Furthermore, there is no reason to believe that a heavy dedicatory stele and a fragmentary one, both referring to the sacred nature of a place, are not related to the site or have been carried to such a steep place.

In an attempt to understand why especially the epithet Selinaios was given to Apollo, after a survey in ancient and early medieval greek literary sources, over 1220 occurrences of the word "selinon" and its derivatives were found, attributing to celery various properties and symbolisms. The great majority of texts either stress the medical properties of the plant (eg. For Galen and Hippocrates: Kuhn, 1821-1833, VI, 637 and Index; Kühn and Fleischer, 1989 398, 730) or relate it, directly or indirectly, with death and chthonian (earthly) powers personified in various local heroes. Such a connection insinuate the fact that celery leaves were used to adorn tombs (Plut., Tim.26.1.2) while crowns made of celery leaves were offered to the winners of the Pan-Hellenic games at Nemea and Isthmia, in NE Peloponnese (Broneer, 1962), commemorating, in the first case, the death of the child-hero Ofeltes (Paus., 8. 48. 2) killed by a dragon that was protecting a spring, and at Isthmia, the child-hero Melikertes-Palaimon (Gebhard, 1993) who was worshipped in a temple with an underground passage leading to an adyton, as Pausanias (2.2.1) describes it.

According to the dating of the two inscriptions and the surface pottery, the site could have been in use for at least two and a half centuries, between the $4^{\text {th }}$ and $1^{\text {st }}$ centuries BCE. It is not yet known whether its use was uninterrupted during this period, since our knowledge up to now is based on surface finds and a single literary source. Unless further field investigation is undertaken at the site if this is technically possible - an answer to this question cannot be provided, since the archaeological data available so far are not enough. The same holds true for determining the period it was founded, when it was abandoned and why. What is sure, is that the site has suffered severe damages, so that only sparse architectural and epigraphical relics are remaining today. One -natural- process of degradation is rockfalls, the present-day morphology suggesting that at least part of the site may have slid away into debris now at the base of the cliff.

\section{Regional geodynamic setting}

The geodynamic province of "Central Greece" has been witnessing active crustal extension at a rate of about $10 \mathrm{~mm} / \mathrm{yr}$ during most of the Quaternary (e.g. Jackson, 1994). The latest (Pleistocene) phase of the extension is responsible for the formation of the Northern Evoikos Gulf (e.g. Philip,1974; Lemeille, 1977; Rondogianni, 1984), a graben bound by a series of WNW-ESE to NW-SE fault zones which are active as of today (Figure 4). On the mainland side, the graben is bound by the NNE to NE-dipping fault zones of Atalanti and Arkitsa-Kammena Vourla (Afz and AKfz in Figure 4, respectively, e.g. Philip, 1974; Rondogianni, 1984; Kranis, 1999), whereas the Euboea side is defined by the SW-dipping Kandili fault zone $(\mathrm{Kfz})$ as well as other zones on the side of Euboea (Rondogianni, 1984; Roberts and Jackson, 1991; Ganas, 1997 and many others). The activity of these fault zones has strongly influenced the landscape evolution of the region, and is related with significant historical (e.g. Bousquet and Pechoux, 1977; Rondogianni, 1984; Papaioannou et al., 1994 and several others) and instrumentally recorded seismicity (e.g. Papanastassiou et al., 2001).

A further important element of the regional geodynamics is volcanism, focused in the broader area around the Lichades islands (star n. 1 in Figure 4), which consist of Pleistocene volcanics (Fytikas 


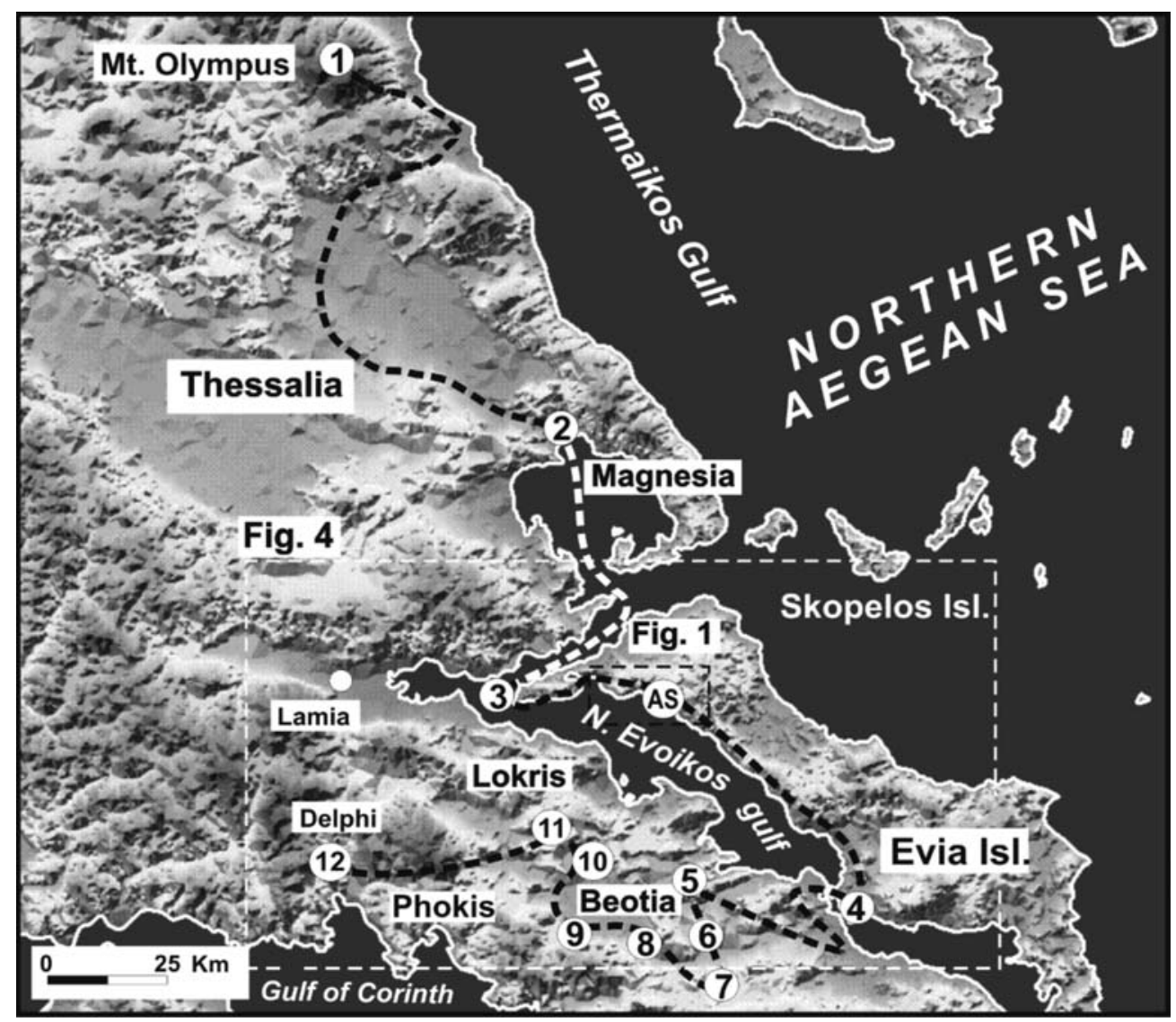

Fig. 3: The route Apollo followed from Mt. Olympus to Delphi on his quest for an appropriate place to found an oracle, according to the Homeric "Hymn to Apollo". Numbers indicate places mentioned in the Homeric 'Hymn to Apollo' including those where Apollo founded oracles before ending up in Delphi (the oldest and the most important oracles of Apollo, more recent ones being located in Asia Minor, on the islands of Lesvos, Lemnos and Delos, and one in Peloponnesos). It is remarkable that the oracles in their majority have been founded within the greater area between the Northern Evoikos Gulf and the gulf of Corinth, two major neotectonic graben trending WNW-ESE to NW-SE, which are associated with the most intense seismicity of mainland Greece.

1: Mt. Olympus, 2: Iolkos, 3: Cape Kenaeon, 4: Lelantion Field, 5: Ptoon Mt., oracle of 'Ptoos Apollo', 6: Ismenion, oracle of 'Ismenios Apollo', 7: oracle of Apollo in Isiae, 8: oracle of Apollo in Eutresis, 9: Telphoussa, 10: oracle of Apollo in Tegyra, 11: oracle of Apollo in Avai, 12: Delphi, where the most famous of Apollo's oracles are located, AS: The site at Ag. Taxiarches near Oroviai discussed herein. Oracle names from Ragavis (1888).

et al., 1984). Older, Miocene-age volcanic rocks are found at Chronia, SE of Rovies (star n. 2 in Figure 4, Lemeille, 1977; Katsikatsos et al., 1980). Volcanic activity has formed a significant number of thermal springs around Northern Evoikos, as in Hypate, Thermopylae (=hot gates or gates of thermal springs), Aedipsos (e.g. Kelepertsis et al., 2009) and Yialtra in N. Euboea, and at Limni (9 $\mathrm{km}$ SE of Rovies) and Helia (Figure 4; Sfetsos, 1988). The thermal springs are often found along fault zone traces and especially at their intersections. In the case of Aedipsos, the hydrothermal springs are related to extensive travertine deposits (e.g. Hancock et al., 1999). 


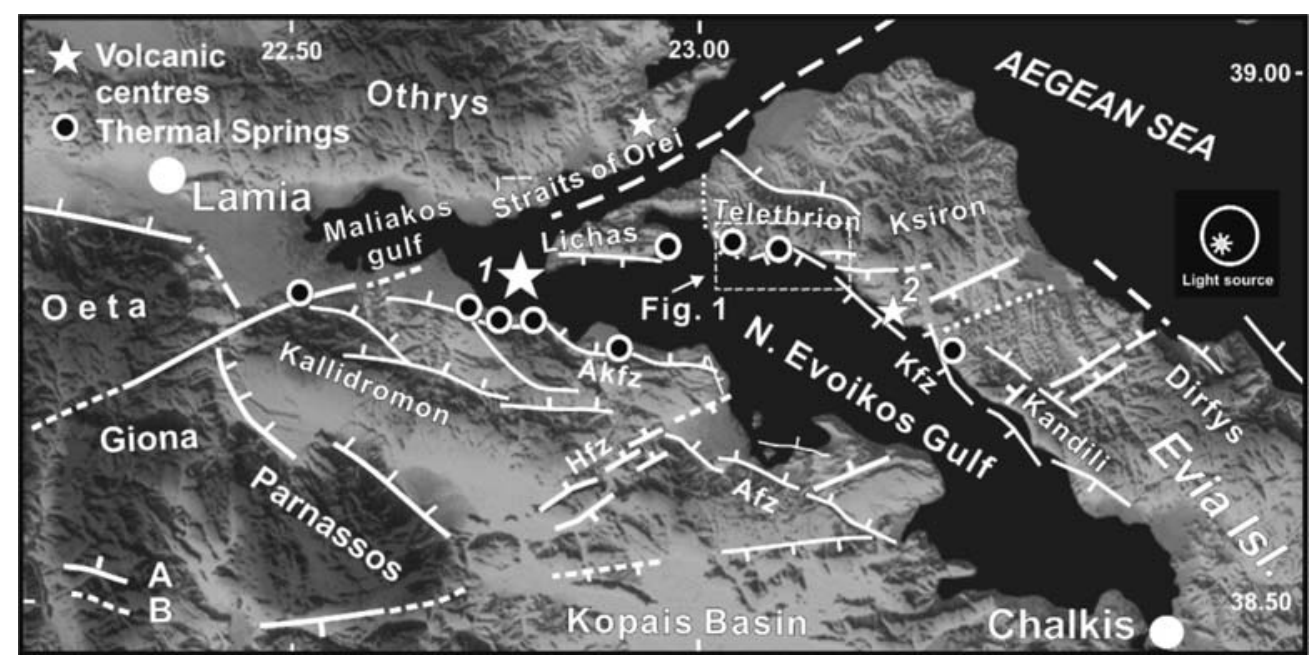

Fig. 4: The Northern Evoikos Gulf graben and surrounding area. Faults from Philip (1974), Katsikatsos et al. (1984), Rondogianni (1984), Kranis (1999), Palyvos et al. (2006), Van Andel \& Perissoratis (2006) and references therein. Major thermal spring locations reproduced from Sfetsos (1988), volcanic centres from IGME maps. The existence of the thermal springs is attributed to the Lichades Quaternary volcanic centre (large star) and the presence of many active faults, along which -and especially at their intersections- the occurrence of these springs is favoured. Older volcanic centres are those of Chronia and Achillion (marked with a smaller star). A: normal fault (ticks on downthrown side), B: probable fault or fault extension.

\section{Geological and geomorphological environment of the site}

The ruins of the site discussed herein are located about $420 \mathrm{~m}$ North of the chapel of Aghios Taxiarches, on a south-facing slope of Mt. Telethrion overlooking the N. Evoikos gulf (Figures 1 and 5). Mt. Telethrion is part of the highest mountain range (700-990 m) of the northernmost part of Euboea (Figure 5).

The northernmost part of Euboea is dominated by Lower Miocene to Lower Pleistocene fluvio-lacustrine deposits of the Limni-Istiaia basin (Mettos et al., 1992). Uplift of the Telethrion range during the Quaternary has resulted in the removal of the original cover of Neogene deposits and the extensive exposure of alpine bedrock. In specific, the Mt. Telethrion consists of Upper Paleozoic to Middle Jurassic metamorphic rocks belonging to the Pelagonian geotectonic unit of the Hellenides. In the broader area around the oracle of Apollo, greenstones (meta-volcanics) with intercalations of schists and phyllites occur (Katsikatsos et al., 1984). These are interpreted to be the product of submarine extrusions of basic igneous rocks, mainly diabasic and basaltic, that were epizonally metamorphosed during the Alpine orogenetic cycle (Katsikatsos et al., 1984). Within the above formation, intercalations of Middle Triassic white-grey crystalline limestones can be found (Katsikatsos et al., 1984).

The morphology of the S-SSW face of Mt. Telethrion is characteristically straight and steep (Figures 1 and 5), its slopes descend to the sea with the deepest waters of the Northern Evoikos Gulf in front of them (>400 m - Figure 1). This morphology is the geomorphic expression of a presumably active fault zone directed roughly WNW-ESE, which bounds this part of the Northern Evoikos gulf graben to the N-NNE (Figure 4) - e.g. Van Andel \& Perrissoratis (2006). Triangular facets, features typical of fault-bounded range-fronts (e.g. Burbank and Anderson, 2001) are present on the slopes of Mt. Telethrion (Figure 5). The ruins are located near the base of one of these facets $(\sim 800 \mathrm{~m}$ high - Figures 1 and 5), under the highest peak of Mt. Telethrion (970 m). 


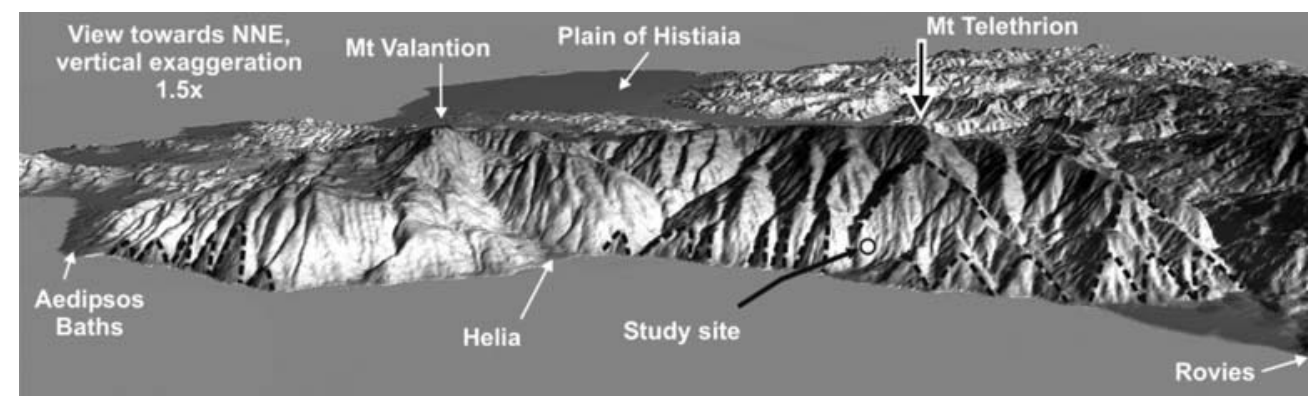

Fig. 5: Digital Terrain Model of Mt. Telethrion, where the study site is located. 3-D view from SSE towards NNW, vertical exaggeration 1.5x. DTM resolution is $20 \mathrm{~m}$, interpolated from $20 \mathrm{~m}$ contours of HAGS 1:50.000 maps. The straight and steep morphology is due to the presence of a NW-SE active fault zone bounding Telethrion to the SW. Dashed lines mark triangular facets on the mountain front, in between deep wine-glass and V-valleys that dissect it. The large facet on which the study site is located, is drawn simplified (it can be subdivided in one upper facet and two lower ones).

In the 1:50,000 geological map of the Institute of Geological and Mineral Exploration (IGME - Katsikatsos et al., 1984) the respective fault zone along is traced at the base of the facet where the ruins are located, as a discontinuity that brings into contact the middle Triassic metavolcanics / crystalline limestones formation with Permian metaclastics (modified fault trace 'A' in Figure 1). The orientation of the fault zone at the base of the facet (and the facet itself) is oblique relative to the general direction of the offshore fault zone that bounds Mt. Telethrion to the SW (' $\mathrm{C}$ ' in Figure 1). We consider fault zone A to be part of a different group of neotectonic structures (rather than a splay of the offshore fault zone C), because of (a) the existence of a second fault zone with this same direction farther SE (fault zone 'B' in Figure 1, which juxtaposes Neogene deposits against rocks of the Pelagonian unit), and (b) the existence of probable neotectonic faults with the same general direction crossing this part of Northern Euboea farther ESE (Palyvos et al., 2006 and references therein).

In most of its extent, the facet with the ruins is more or less concave in cross profile, consisting of easily erodible metamorphosed clastics (1b in Figure 1). Its SW tip though (where the ruins are located), consists of the metavolcanics of the Telethrion escarpment and the largest occurrence of crystalline limestones inside them (1a in Figure 1), both very hard lithologies, resulting in the specific part of the facet being steep and convex in profile. The morphological surroundings are particularly imposing: apart from the steepness of the bedrock escarpment, the site is located next to a very scenic waterfall more than $70 \mathrm{~m}$ high, at the exit of a small hanging valley (Figures 6 and 7).

The crystalline limestones / metavolcanics contact at the area of the ruins is dipping to the NE and it is well defined and readily observable on the western side of the hanging valley, all the way to the valley bottom (Figure 6). At the eastern side of the valley the metavolcanics disappear abruptly, and the escarpment facet in this specific part consists of limestones only. This is so because the contact is interrupted by a NE-SW trending, SE-dipping normal fault down throwing to the SE, which will be called ' $\mathrm{F} 1$ ' in the discussion that follows. We consider fault $\mathrm{F} 1$ to be a secondary splay of the facetbounding fault zone A shown in Figure 1. Fault F1 was observed a few tens of meters $\mathrm{W}$ of the walling remains, and together with other discontinuities, relates to the presence of a cave that was discovered between the walling remains and the waterfall during our reconnaissance (Figures 6, 8 and 9).

The cave is found on the upthrown (footwall) block of fault F1, right next to the fault. The SE wall of the cave is the very well preserved polished fault plane of fault F1 (Figures 8 and 9) that dips 81- 


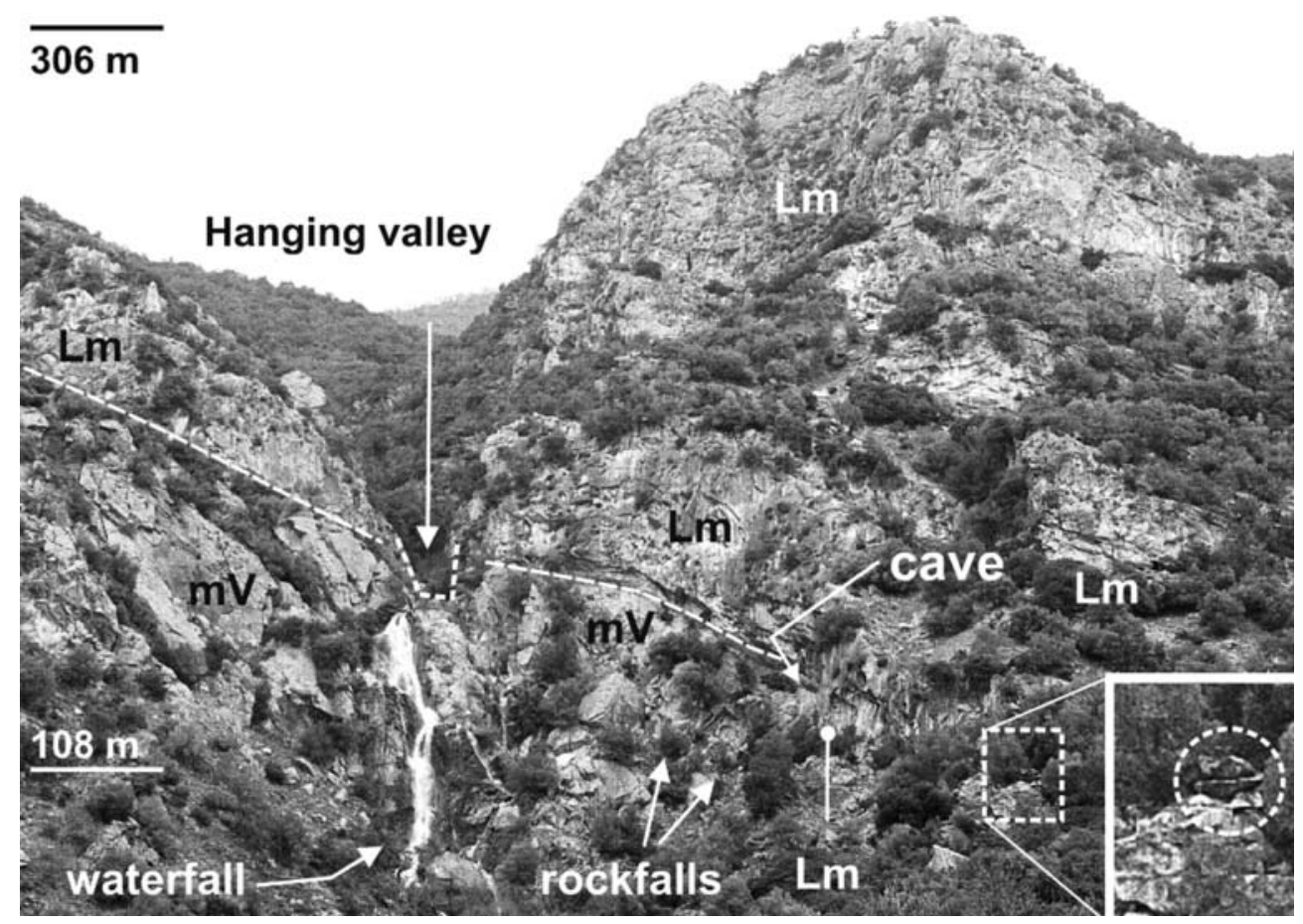

Fig. 6: Photograph of the escarpment where the study site is located (view from the South). Walling remains are visible in the zoomed-in part of the photograph, near a hanging valley and a very scenic waterfall more than $70 \mathrm{~m}$ high. The escarpment consists of crystalline limestones (Lm), over metavolcanics (mv), their contact (marked with a dashed line) dipping around $27^{\circ}$ towards the NE. Where the cave is located (entrance facing to the left of the photo, not visible in the photo), the contact is downthrown by a normal fault parallel to the escarpment (see text), and only limestones are exposed in the vicinity of the walling remains. Elevations taken from a 1:5.000 topographic diagram of the Hellenic Army Geographical Service are also shown.

$85^{\circ}$ towards $\mathrm{N} 153-163^{\circ} \mathrm{E}$, with striations $\left(70^{\circ} / 226^{\circ}\right)$. A thick travertine deposit occurs along the plane of F1 (Figures 8 and 9b). The ceiling of the cave is the floor of the crystalline limestones of the upthrown fault block, whereas the NW wall consists of the metavolcanics that are found below them, bounded by a succession of at least three discontinuities with more or less the same strike as F1 (Figure 8b). Furthermore, the polished fault plane of F1 is interrupted by a transverse fault (F2 in Figure $8 \mathrm{a}$ and $9 \mathrm{a}$, dipping $85^{\circ}$ towards $\mathrm{N} 252^{\circ} \mathrm{E}$ ). All these discontinuities pre-defined the shape of the cave, whose formation was initiated by groundwater circulation along the limestone / metavolcanics contact (permeable and impermeable, respectively). The bases of three large stalactites -that are broken today- are found on the cave ceiling (Figures. 8 and 9a), their positions defined by joints cross-cutting the limestones. Dripping water along parts of the cave is still observed today.

The present form of the cave is probably the result of subsequent removal by mass wasting of the metavolcanics under the floor of the limestones on the upthrown block of F1. It is characteristic that, when observing the escarpment from the south, on the western side of the hanging valley and the waterfall the metavolcanics systematically protrude underneath the crystalline limestones above them. On the contrary, in the vicinity of the cave, the limestones are seen overhanging above the metavolcanics, giving to the observer the sense of removal of a significant mass of metavolcanics 


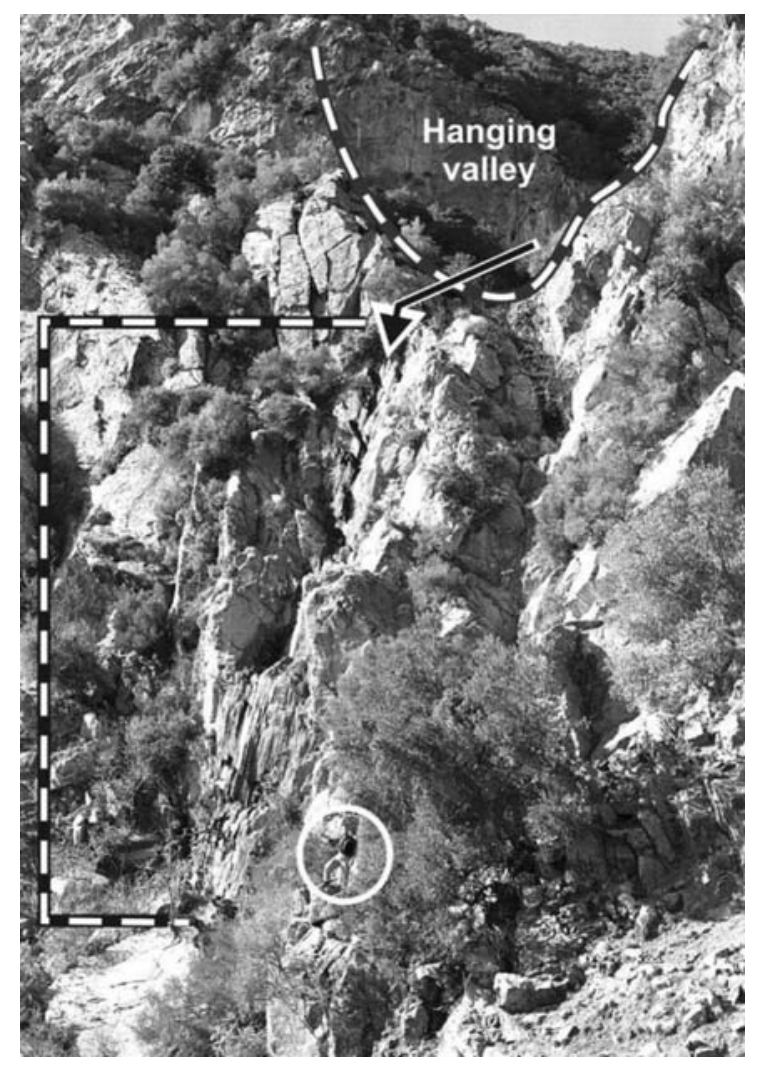

Fig. 7: View of the hanging valley and high waterfall immediately to the West of the wall remains and cave at the study site. The person (in white circle) shown for scale, underestimates the height of the waterfall since he does not stand immediately in front of it.

underneath them (Figure 6 - rockfalls can be seen also on the slope in front of this area). This may be due to more intense rock fracturing because of the intersection of two faults and differences in mechanical behaviour between the limestones and the metavolcanics.

\section{Discussion and open questions}

Recent works point out the straightforward connection between geological features and phenomena (mostly related to the presence of an active normal fault zone, in specific) and the selection of the particular site for the oracle of Delphi, the major oracle of Apollo in Central Greece (Piccardi, 2000; de Boer and Hale, 2000; de Boer et al., 2001). They discuss Plutarch's and other ancient authors' description of the process of divination over a chasm from which gasses where emitting, provoking a state of 'ecstasy' to the priestess of the oracle, and they provide geological evidence which supports the validity of the ancient sources, proposing that the oracular chasm indeed existed in the form of a fissure related to a ground-rupturing active fault or an associated extensional fracture. Piccardi (2000) identified such a fault (paralleling the general direction of the Delphi fault zone) that runs through the shrine of Athena at Delphi, where the primitive sanctuary of the 14th century BCE was also located. De Boer and Hale (2000) have shown that the shrine of Apollo (at a location different than the shrine of Athena) is located at the intersection of the Delphi fault zone and a conjugate swarm of NNW-SSE fractures, along which a number of springs were found (de Boer and Hale, 2000). Chemical analyses of spring waters and travertine deposits realized by de Boer et al. (2001) have proved that light hydrocarbon gasses were emanating with the spring waters at Delphi, origi- 

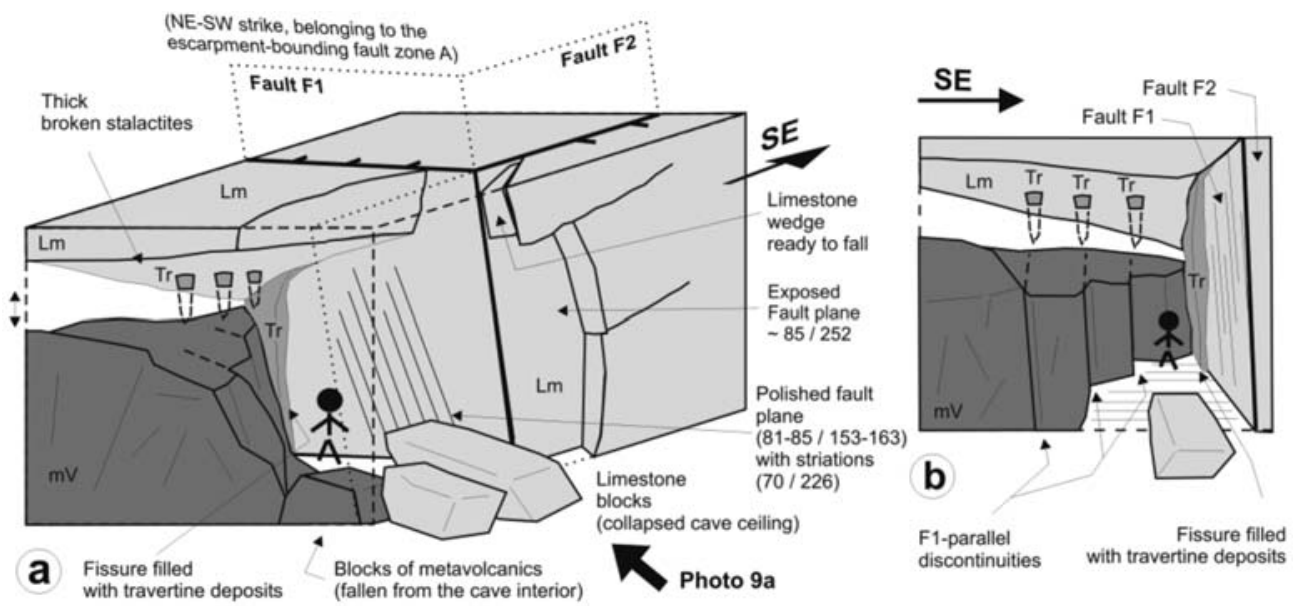

Fig. 7: 3D sketch of the cave lying on the very steep slope immediately West of the ruins. The formation of the cave was directed by a NE-dipping crystalline limestones $(\mathrm{Lm}) /$ metavolcanics $(\mathrm{mV})$ contact, which forms the ceiling of the cave, fault F1, the polished fault plane of which constitutes the SE wall of the cave, fault F2 striking transverse to F1, and faults striking parallel to F1 inside the metavolcanics in its upthrown (footwall) block. A fissure along fault F1 is filled with travertines (Tr). Ticks indicate downthrown (hangingwall) fault blocks.

nating from the underlying strata of bituminous limestones. Among these gasses ethylene was detected, which, upon inhalation causes effects that match those described for the prophetic vapours in ancient texts (de Boer et al., 2001).

Taking into account the initial dedication of oracles to Gaia (earth) and Poseidon, the god of earthquakes, and the fact that earthquakes are closely related to myths regarding the Delphic oracle (Polimenakos, 1996; Piccardi, 2000), preference to the particular type of environment for the oracle of Delphi may be attributed to the fact that it most vividly reflects the 'underworld' (chthonian) powers, which, in modern terminology would be geodynamic phenomena. In a passage referring to a steep escarpment in the valley of Peneos in Thessaly, Herodotus explicitly states: "In my opinion it is the work of an earthquake" (Her. 7, 129,26). This is a clear indication that the connection between earthquakes and changes in the landscape (formation of tectonic landforms) was a notion understood at least as early as Classical times (presumably, also even earlier).

Comparing the landscape features at the oracle of Apollo at Delphi and the site of Aghios Taxiarches we can recognize quite similar geological and geomorphic features (similarity referring to types of landforms found in the landscape, but not necessarily similarity in their sizes or details).

- The oracle at Delphi is also located in front of a 500-700 m high fault escarpment facing to the south, with a WNW-ESE normal fault zone running along its base (Birot, 1959; Aronis et al., 1964; Mariolakos et al., 1989, 1991; Pechoux, 1992; Piccardi, 2000; de Boer and Hale, 2000). The fault zone at Delphi is considered active (e.g. Mariolakos et al., 1989, 1991; Piccardi, 2000; de Boer and Hale, 2000), albeit less active -arguably- than the Telethrion fault zone (judging from their geomorphic expressions).

- In both sites the fault escarpments consist of bedrock: limestones in Delphi, limestones and metavolcanics in Aghios Taxiarches. These hard lithologies result in steep and imposing escarpment morphology, "decorated" with steep cliffs and rock fall scars.

- The oracle at Delphi was also constructed at the mouth of a valley with a gentle upper part, 

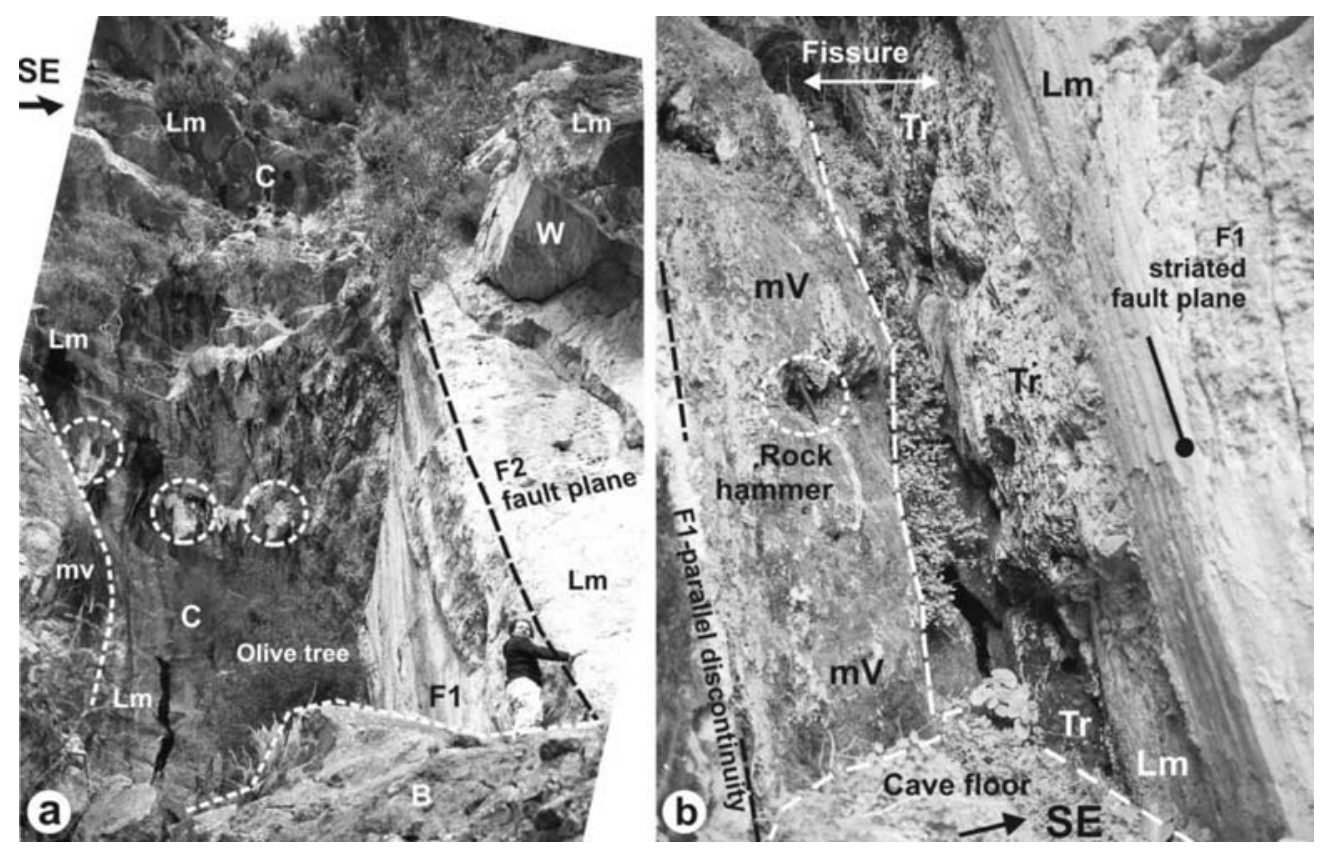

Fig. 8: (a) Oblique view of the cave entrance, looking up from a lower point in the very steep slope in front of it. Lm: Limestone. mV: Metavolcanics. F1/F2: polished fault planes, C: the cave ceiling, dipping away from the reader (=the floor of the limestones, with the metavolcanics -mv- underneath them removed), B: part of a large limestone block fallen from the ceiling. W: large limestone wedge ready to fall off. Thick broken stalactites (dashed-line circles) and newer generations of $\mathrm{CaCO}_{3}$ deposits can be seen on the cave ceiling. (b) The interior of the cave. A large fissure along the polished and striated fault plane of F1 is visible, filled with thick travertine deposits (Tr). The floor of the cave was probably lower during antiquity, now filled with rockfall debris.

hanging above a steep lower part (e.g. Piccardi, 2000). In the case of Aghios Taxiarches the impressive, high waterfall in the lower part of the valley adds to a more "dramatic" landscape; the sacred spring Castallia at Delphi is also typically depicted as a small waterfall.

- In both sites, the presence of carbonates (limestones and crystalline limestones) broken up by joints and fault planes, in combination with impermeable underlying rocks, favoured the presence of springs, spring water being a fundamental element in the process of divination. At the site of Aghios Taxiarches, water is still dripping inside the cave today.

- The oracle springs at Delphi were also associated with thick travertine deposits (e.g. Higgins and Higgins, 1996; de Boer and Hale, 2000).

Considering that studies by Piccardi (2000), de Boer and Hale (2000) and de Boer et al. (2001) have demonstrated that the oracle of Delphi was located in the particular site exactly because of the presence of specific geological features and phenomena, directly connected to the presence of active fault zones, the geological and geomorphological similarities between the site at Aghios Taxiarches and the oracle of Delphi, in our view provide indirect support to the hypothesis that the former can well be the oracle of "Apollo Selinountios" mentioned by Strabo. The cave next to the walling remains should merit consideration as a potential key geomorphological element of the site, considering that use of caves as places of chthonian cult was in fact common in ancient Greece. Some of them were also used as oracles, e.g. the oracle of Trophonios in Leivadeia (Boeotia), which was located at a cave with 
springs inside it (Higgins and Higgins, 1996). In order for a firm connection between the cave and the archaeological remains (walling) nearby to be established, a test excavation inside the cave and a more systematic work on the site in general is necessary. Such studies will probably require special geotechnical considerations given the slope instability problems and the high rock fall hazard. If the cave is indeed found to be related to the use of the nearby site, detailed geological, geomorphological, geochemical and gechronological study could attempt to help addressing questions related to the type of connection the cave may have had with the function of the site. E.g. how different was the morphology of the cave during antiquity, when the nearby site was operational? Was it more enclosed or open more or less as at present? Limestone blocks fallen from the cave ceiling are blocking the entrance of the cave (Figs. 8 and 9a) but, when exactly this collapse took place is not known. How much lower was the cave floor (now filled with debris) in antiquity? What is the age of the travertine deposits inside the cave, and what was the chemical composition of the fluids that deposited the travertines? Were there gas emissions involved, and if yes, of what gasses?

The origin of the travertine deposits along the fault plane of F1 and their relation or not to hydrothermal activity are questions that refer to whether the cave may have served as the adyton (sanctum) of a shrine, with geological features similar to those described by ancient writers for the Delphic adyton (fissure on the ground \& emanating gasses). These questions become very interesting, considering:

- the location of the site within the major hydrothermal field of Northern Evoikos Gulf, the type locality for travertine deposits (of hydrothermal origin) being at nearby Aedipsos (Fig. 5).

- the preferential location of travertine deposits in such fields along normal faults (e.g. Hancock et al., 1999) and especially their intersections, as is the case for the cave.

- the gas emissions associated with hydrothermal springs on the opposite side of the gulf and nearby Aedipsos (e.g. Sfetsos, 1988, Gioni -Stavropoulou, 1998).

Regardless of its exact use in antiquity, given the location of the Agios Taxiarches site in a geodynamically and geomorphologically highly active environment, future detailed studies could also clarify whether geo-environmental factors played a role in its decline (or destruction). Two such possible causes of disturbance of the site's operation could be destructions by strong earthquakes in the broader N. Evoikos graben (nearby Oroviai were devastated during the 426 BCE earthquake (Thuc. 3. 89, Bousquet and Pechoux, 1977), and destructions due to rock falls. Rock falls are greatly favoured by the steepness of the escarpment and the intense dissection of the crystalline limestones and meta-volcanics by numerous joints and fault planes. The talus slopes along the base of the escarpment speak of a long history of rock falls, whereas very recent falls are described by locals (unrelated to strong earthquakes) and evidenced by the large number of fallen boulders in front of the base of the escarpment. Rockfalls could also be related (although not necessarily) to strong earthquakes caused by any one of the fault zones around the N. Evoikos graben, or the Telethrion fault zone itself. Furthermore, strong earthquakes could have caused hydrological disturbances, such as those mentioned for Aedipsos and the broader area in an account of the natural phenomena caused by the large 426 BCE earthquake, given by Strabo (Bousquet and Pechoux, 1977).

\section{Conclusions}

- Two inscriptions, one dedicated to "Apollo Selinaios", and another mentioning a priestess were found at Aghios Taxiarches, $6.2 \mathrm{~km} \mathrm{NW}$ of modern Rovies (where ancient Oroviai are located). The inscriptions, located next to wall ruins, provide strong indications (if not definitive proof) of a shrine of Apollo bearing the epithet Selinaios, unknown from literary and epigraphical sources. 
- Given the vicinity of the site to ancient Oroviai and the new epigraphical material, we propose the hypothesis that the site can well be the "oracle at Oroviai " of "Apollo Selinountios" mentioned only in a single passage of Strabo (and in no other literary or epigraphic source). Considering that epigraphic evidence is stronger than evidence from historical sources, and that Strabo never visited Euboea, it seems very likely that he may have used a wrong version of Apollo's epithet Selinaios (more details in Nikolopoulos, 2005).

- The walling remains at the site are located on the $300 \mathrm{~m}$ high, steep bedrock escarpment of an active normal fault zone. The presence of the fault zone is responsible for a landscape of particular beauty and imposing geomorphological elements, which include steep cliffs and rockfall scars, a hanging valley with a high waterfall and a small cave that has formed at the junction of two faults and has extensive travertine deposits inside it.

- The site at Agios Taxiarches, when compared to the oracle of Apollo at Delphi, is found to be situated in an environment with similar geological and geomorphic features (this referring to types of landforms, not exact similarity). Considering that recent studies have demonstrated that the oracle of Delphi was located in the particular site exactly because of the presence of specific geological features and phenomena that are directly connected to the presence of active fault zones, the geological and geomorphological similarities between the site at Aghios Taxiarches and the oracle of Delphi, in our view provide indirect support to the hypothesis that the former can be the area where an ancient oracle stood.

Systematic archaeological study of the broader area around the walling remains and of the nearby cave should be undertaken, if the hypothesis we propose is to be irrevocably verified. Such a study will probably be technically demanding, considering the steep terrain and high rockfall hazard. Geological/geomorphological, geochemical, and geochronological studies would be necessary to clarify the connection the cave may had with the site's function.

\section{Acknowledgements}

The authors would like to thank Mrs Aggeliki Nikolaou for finding the inscriptions and delivering them to the Ephorate of Antiquities in Chalkis, Euboea, the Director of the Epigraphical Museum in Athens, Dr Charalambos Kritzas for his comments on the text of the inscriptions, Mrs Yiolita Bantekas and Prof. Chary Cliadakis for revising early versions of the manuscript, and two anonymoys reviewers for their constructive comments and suggestions. For the ancient sources references the Loeb Classical Library series (London - Cambridge Massachusetts, Harvard Univ. Press) was used.

\section{References}

Ambraseys, N.N. (1996). Material for the investigation of the seismicity of Central Greece. In S. Stiros \& R.E. Jones (Eds). Archaeoseismology (pp. 23-36). Fitch Lab. Occas. Paper 7. British school at Athens.

Aronis, G., Panagiotidis, Gr., Monopolis, D. \& Morikis, A. (1964). Geological map of Greece in 1:50.000 : Delphi sheet. Athens, Institute for Geology and Subsurface Research.

Birot, P. (1959). Geomorphologie de la region de Delphes. Bulletin de Correspondance Hellenique, 83, 258-274.

Bousquet, B.\& Pechoux, P.Y.(1977). La seismicite du bassin Egeen pendant l'Antiquite. Bull. Soc. Geol. France, (7) XIX (3), 679-684.

Broneer, O. (1962). The Isthmian victory crown. American Journal of Archaeology, 66, 259-263.

Burbank, D. W. \& Anderson, R. S. (2001). Tectonic Geomorphology. Blackwell Science. 
Bursian, C. (1872). Geographie von Griechenland. Band II, Leipzig.

Darmezin, L. (1999), Les affranchissements par consécration en Béotie et dans le monde grec hellénistique, Nancy.

De Boer, J. Z. \& Hale, J. R. (2000). The geological origins of the oracle at Delphi, Greece. In W.G. Mc Guire, D. R. Griffiths, P. L. Hancock \& I. S. Stewart (Eds). The Archaeology of Geological Catastrophes (pp. 399-412). Geological Society, Sp. Publ., 171, London.

De Boer, J. Z., Hale, J. R. \& Chanton, J. (2001). New evidence for the geological origins of the ancient Delphic oracle (Greece). Geology, 29, 8, 707-710.

Fytikas, M., Innocenti, F., Manetti, P., Mazzuoli, R., Perccerillo, A. \& Villari, L. (1984). Tertiary to Quaternary evolution of volcanism in the Aegean region. In J.E. Dixon \& A.H.F. Robertson (Eds.). The geological evolution of the Eastern Mediterranean (pp. 687-699). Geol. Soc. London, Spec. Publ. 17, Blackwell Oxford.

Ganas, A. (1997). Fault segmentation and seismic hazard assessment in the gulf of Euboea rift, Central Greece. PhD dissertation, University of Reading.

Gebhard, E., (1993), The Evolution of a Pan-Hellenic Sanctuary: From Archaeology towards History at Isthmia, in N. Marinatos, R. Hägg (eds.) Greek Sanctuaries, New Approaches, 154-177.

Gioni-Stavropoulou, G. (1998). Hydrogeological study of Hydrogeological - Hydrochemical conbditions of the Loutra Aidipsou hydrorthermal field. Institute of Geology and Mineral Exploration, report of project 9261904, 29 pp. (in Greek)

Hancock, P. L., Chalmers, R.M.L., Altunel, E. \& Cakir, Z. (1999). Travitonics: using travertines in active fault studies. Journal of Structural Geology, 21, 903-916.

Higgins, M.D. \& Higgins, R. (1996). A geological companion to Greece and the Aegean. London, Ducksworth and Co.

Jackson, J. (1994). Active tectonics of the Aegean region. Ann. Rev. Earth Plan. Sci., 22, 239-271.

Katsikatsos, G., Mettos, A. \& Vidakis, M. (1984). Geological Map of Greece in 1:50.000: Istiea sheet. Athens, Institute of Geology and Mineral Exploration (IGME).

Katsikatsos, G., Kounis, G., Fytikas, M., Mettos, A. \& Vidakis, M. (1980). Geological Map of Greece in 1:50.000: Limni sheet. Athens, Institute of Geology and Mineral Exploration.

Kelepertsis, A., Tziritis, E., Kelepertsis, E., Leontakianakos, G., Pallas, K., 2009. Hydrogeochemical characteristics and genetic implications of Edipsos thermal springs, North Euboea, Greece. Central European Journal of Geosciences, 1(3), 241-250.

Kranis, H. (1999). Neotectonic activity of Fault zones in central - eastern Sterea Hellas (Lokris), PhD Dissertation, University of Athens (in Greek).

Kuhn, K.G.(1821-1833). Claudi.Galeni Opera Omnia, Vls. VI, XX, Lipsiae.

Kühn, J.H \& Fleischer, U. (1989). Index Hippocraticus, Göttingen.

Lemeille, F. (1977). Etudes neotectoniques en Grece Centrale Nord-orientale et dans les Sporades du Nord (ile de Skyros). PhD Dissertation, Univ. Paris XI - Centre d' Orsay.

Mariolakos, I. (2001). The geoenvironmental dimension of Greek mythology. Bulletin of the Geological Society of Greece, XXXIV/6, 2065-2086 (in Greek).

Mariolakos, I., Logos, E. \& Lozios, S. (1989). Geological - Geotechnical - Neotectonic studies in archaeological sites (phase A). Project Report for the Ministry of Culture, Directorate of Prehistoric and Classical Antiquities, Athens.

Mariolakos, I., Logos, E., Lozios, S. \& Nasopoulou, S. (1991). Technicogeological observations in the ancient Delphi area (Greece). Proc. of the European school of climatology and natural hazards course 
(Lisbon, March 28- April 5, 1990). Commission of the European Communities, Directorate-general, Science, research and development publ. 12918, 273-283.

Mayer, L. (1986). Tectonic geomorphology of escarpments and mountain fronts. In R. E. Wallace (Ed.). Studies in Geophysics: Active Tectonics (pp. 125-135). National Academy Press, Washington D.C.

Mercier, J. L., Sorel, D., Vergely, P. \& Simeakis, K. (1989). Extensional tectonic regimes in the Aegean basins during the Cenozoic. Basin Research, 2, 49-71.

Mettos, A., Rondogianni, Th., Ioakim, Ch. \& Papadakis, I. (1992). Evolution geodynamique et reconstruction paleoenvironnementale des basins neogenes-quaternaires de la Grece centrale. Paleontologia i Evolucio, 24-25, 393-402.

Nikolopoulos, V., 2005. Manteio tou Apollonos stis Rovies Euvoias. Etaireia Evoikon Spoudon, Archeion Evoikon Meleton, $\Lambda \mathrm{E} / 2003-204,9-18$. (in Greek)

Palyvos, N., Bantekas, I. \& Kranis, H. (2006). Transverse fault zones of subtle geomorphic signature in Northern Evia island (Central Greece extensional province) : An introduction to the Quaternary Nileas Graben. Geomorphology, 76, 363-374.

Papaioannou, J., Makropoulos, K. \& Kouskouna, V. (1994). Revision of some historical earthquakes in central Greece. Proc. Of the XXIV European Seismological Comission general assembly, Athens, Sep. 19-24 1994, 1711-1713.

Papanastassiou D., Latoussakis J. \& Stavrakakis, G. (2001). A revised catalog of earthquakes in the broader area of Greece for the period 1950-2000. Bulletin of the Geological Society of Greece, XXXIV (4), 1563-1566.

Parke, H. W. (1939). A History of the Delphic Oracle, Oxford, 6-7.

Parke, H. W. (1967). Greek Oracles, London, 93-94.

Pechoux, P.-Y. (1992). Aux origins des paysages de Delphes. In J. F., Bommelaer (Ed.). Delphes (pp. 138), Univ. Strasbourg II, publ. 12.

Philip, H. (1974). Etude neotectonique des rivages egeens en Locride et Eubee nord-occidentale (Grece). PhD Dissertation, Acad. De Montpelier.

Piccardi, L. (2000). Active faulting at Delphi, Greece: Seismotectonic remarks and a hypothesis for the geologic environment of a myth. Geology, 28, 7, 651-654.

Ragavis, A. (1888). Lexikon tis Ellinikis Archaiologias, Athens.

Roberts, S. \& Jackson, J. (1991). Active normal faults in central Greece: an overview. Geol. Soc. of London Sp.Publ. 56, 125-142.

Rondogianni, Th. (1984). Etude neotectonique des rivages occidentaux du canal d'Atalanti (Grèce centrale). PhD Dissertation, Universite de Paris Sud, Centre d' Orsay.

Sackett L. H., Hankey V., Howell R.J., Jacobsen T. W. \& Popham M. R., (1966). Prehistoric Euboea: Contributions toward a Survey. Ann. of the Brit. Sch. at Athens, 71 (25), 39 - 46.

Sakellariou, D., Rousakis, G., Kaberi, H., Kapsimalis, V., Georgiou, P., Kanellopoulos, Th., Lykousis, V., 2007. Tectono-sedimentary structure and Late Quaternary evolution of the North Evia Gulf basin, Central Greece: preliminary results. Bulletin of the Geological Society of Greece, XXXX, 451-462.

Sfetsos, C. S. (1988). Inventory of thermal and mineral springs of Greece (III Continental Greece). Hydrological and Hydrogeological investigations, No. 39, IGME, Athens.

Van Andel, T.H. \& Perissoratis, C. (2006). Late Quaternary depositional history of the North Evvoikos Gulf, Aegean Sea, Greece. Marine Geology 232, 157-172. 